\title{
RURAL TOURISM AND SUSTAINABLE RURAL DEVELOPMENT OPPORTUNITIES IN APULIA REGION (SOUTHERN ITALY)
}

\author{
Donatello Caruso ${ }^{1}$, Albert-Pol Miró ${ }^{2}$ \\ ${ }^{I}$ Department of Economics, University of Foggia, L.go Papa Giovanni Paolo II, Foggia, Italy \\ ${ }^{2}$ Department of Economics, University of Vic, Sagrada Familia Street, VII, Vic, Spain \\ E-mails: 'donatello.caruso@unifg.it (corresponding author); ${ }^{2}$ albertpol.miro@uvic.cat
}

\begin{abstract}
The purpose of this study is to investigate the public aid role in to multifunctional farms in developing the rural tourism, and the implementation in non-agricultural activities in the Puglia region. Concretely, by referring to the Rural Development Program 2007/2013, this paper offers an analysis to verify whether there is a solid support for public aid in agrotourism using a farm level data. After a policies and literature review on the role of the Local Action Groups (LAGs) for enhancing economic and sustainable competitiveness of rural areas, we present our case study. Statistical analysis and a tree classification method are carried out.
\end{abstract}

Keywords: Rural Development Program, agrotourism, CHAID decision tree algorithm, Apulia region, sustainability, rural tourism.

JEL Classification: Z3; R11; Q18.

\section{Introduction}

The European Agricultural Fund for Rural Development is an EU source of finance. Thus it is being used by Member States to archive a variety of EU rural development policy goals such as: improving the competitiveness of farms, forest and agri-food businesses; helping protect the natural environment; supporting rural economies and quality of life in rural-areas.

Tourism is an activity encompassing economy, society and nature (Schaerer, Dirven 2001). Within this context, alternative tourism offers quality products and services, puts emphasis on the local character and provides "authentic" experiences and personal contact between the tourist and the supplier of the service (Psaltopoulos, Efstratoglou 2000).

One of the forms of alternative of mass tourism is rural tourism and more specifically agrotourism. It is understood by tourism in rural areas which carry out urban residents owners of second homes in rural areas, which occupy the weekend or older, or lapses rent them to tourists as well as tourism to spend the night in implantations type Resort, Hotel or Motel in rural area (Aggelopoulos et al. 2006).

Rural tourism and its linkages to input suppliers and services have emerged in several forums as a proposal to diversify the rural economy and create a news job and additional income (Van der Ploeg et al. 2000).
Rural tourism can be considered as a sustainable activity and serve as a basis for sustainable and increase regional economics (Chen 2011; Liu et al. 2011; Sanagustin Fons et al. 2011).

Note that this is much more recent phenomenon in the Mediterranean basin than in Northern Europe, for instance Britain, Germany, Netherlands and Belgium, etc. In contrast, in the European Mediterranean countries, the rural exodus was much delayed and it is only recently that the bonds between country and city haven been broken by this situation the way carried in the European Mediterranen countries have been slower than in Northern Europe.

In our case study, we work with a country in the European Mediterranean coutnries, as is Italy, specifically, the region of Southern Italy, the region of Puglia.

Therefore, the Rural Development Programme for Puglia Region 2007-2013 (Management Authority of the Rural Development Plan of the Puglia Region 2007-2013) has identified, as a special measure, the encouragement of rural tourism activities. The Measure 311 (Axes III) of the Rural Development Program adopted by the Region of Puglia has the main aim of pursuing - in accordance with art. 20(b) (i) of Council Regulation (EC) No. 1698/2005 and art. 42 No. 1305/2013 of Council Regulation (EC) - the diversification into non-agricultural activities through grants for investments. Its importance is

(C) 2016 The Authors. Published by VGTU Press. This is an open-access article distributed under the terms of the Creative Commons Attribution License (CC-BY 4.0), which permits unrestricted use, distribution, and reproduction in any medium, provided the original author and source are credited. 
being shown by the allocation of 31.303 million Euros for the program. Moreover, rural tourism promises an opportunity for the diversification of activities for persons engaged in agriculture (Hjalager 1996; Sharpley, Vass 2006).

The increasing development of non-agricultural activities in rural-areas has contributed largely to the formation of a "new rurality" characterising more and more the rural regions of Europe (Kasimis 2010).

Within this framework, it is important to get an insight into the effectiveness of EU and regional policy such as an essential tool in reaching several objectives including those to promote the development of competitiveness in rural-areas. In the present paper, we shed some light on the successful positive influence for farmers diversifying its activities with the tourism, by means of implementation of the diversification into non-agricultural activities throughout the new tourism in ruralareas, measure 311, action 1 of Rural Development Programme (RDP).

In addition, the secondary purpose is to verify the possibility to classify the annual investment respect to the some defined variables in order to select groups and predict how their responses to some variables affect other variables.

\section{Previous research}

EU rural development policy is also of considerable importance for the tourism sector. Through the European Agricultural Fund for Rural Development (EAFRD) the Commission can support, among other things, the establishment of businesses active within rural tourism, the development and promotion of agri-tourism and capitalisation on the cultural and natural heritage of rural regions, including mountain areas.

The analysis of the literature refers, how some authors already highlighted fifty years ago, how agriculture could strategically contribute to economic development under various aspects such as resources use, production improvements in both quantitative and qualitative terms, and foreign exchange (Johnston, Mellor 1961; Kuznets 1964; Mellor 2000).

In the context of the EU and the CAP, rural development aims at safeguarding the economy of the countryside by supporting programmes to invest, modernize and support activities - both agricultural and non-agricultural - in rural-areas for improving growth process and income situation (Farm Accountancy Data Network 2010). Eurostat data on the Entrepreneurial Income of Agriculture, for the period 2005-2013, confirm that revenues for the agricultural system fluctuated considerably. In 2013 there were levels of EU-15 income, slightly below the level as 2005 . From the base year of 2005, the EU-28 index rose for two consecutive years, before falling back in 2008-2010 (at the height of the financial and economic crisis) strongly below the level as 2005 (Ciani 2012).

In this sense, Rural Tourism is one of the main opportunities in terms of potential growth for rural- areas. In fact, the overall importance in terms of standard output, of the Agricultural holdings that undertake a Tourism services, in EU-28 Countries amounts to $12.5 \%$, after contractual work $(39.1 \%)$ and both processing farm product and production of renewable energy that amount at $18.7 \%$ (Eurostat 2013). As remarked in official report from European Commission (2013a), the tourism infrastructure, i.e. the number of bed places available in tourist accommodations, is not equally distributed across the EU, with nearly $90 \%$ of all bed places located in the EU-15. Two countries alone - France and Italy - represent around $40 \%$ of the EU-15 bed places, and another three countries - Germany, Spain and the United Kingdom - each represent around $12 \%$. Also among the EU-N12 there are two countries which represent more than $40 \%$ of the total number of bed places, namely Poland $(24.9 \%)$ and the Czech Republic $(18.9 \%)$. In the figure below (e.g. see Fig. 1), it can be observed how For the EU-27 as a whole, the share of available bed places is higher in predominantly rural regions $(32.2 \%)$ than in predominantly urban regions $(25.3 \%)$. The distribution of bed places among the EU-27 Member States shows that some countries represent a higher share of "rural" bed places than their share of bed places at national level, highlighting the importance of rural

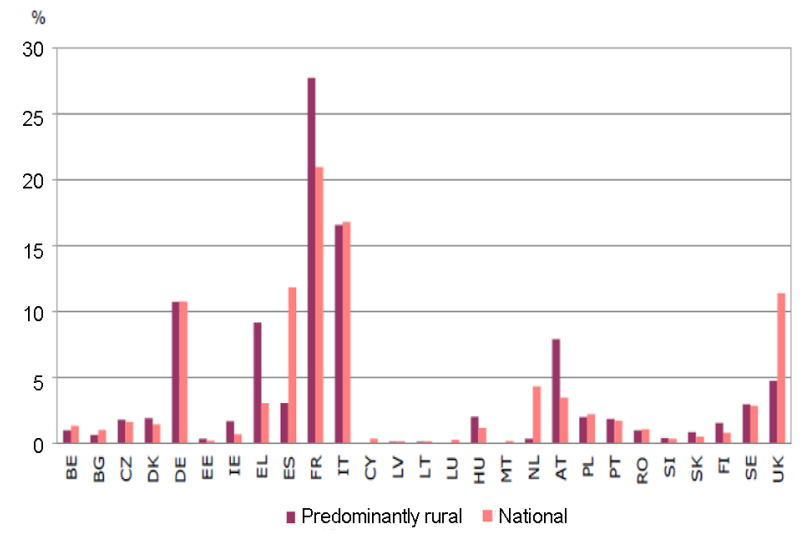

Fig. 1. Distribution of bed places in tourist accommodations in the predominantly rural regions and at national level among the EU Member States, 2011

(Source: European Commission 2013b) 
tourism in these countries. For example, France, Greece and Austria represent 27.8\%, 9.1\% and $7.9 \%$ of the "rural" bed places in the EU-27 and only $21 \%, 3 \%$ and $3.4 \%$ of the total EU-27 bed places, respectively. Moreover, one out of three EU-15 "rural" bed places is in France and one out of four EU-N12 "rural" bed places is in Hungary.

The importance of multifuncional farming activities is remarkably evidenced by the significant changes made to the EU's CAP, within its rural development policy, that represents the future of the EU rural communities and shapes the agricultural future (Andrei, Darvasi 2012; Popescu, Andrei 2011), so the process of diversification into non-agricultural activities, has received a lot of attention over the last decade from scholars and policy-makers (OECD 2003, 2005, 2006, 2008; ENRD 2010; Ohe 2007; Stoate 2008; van der Ploeg et al. 2009; Jongeneel et al. 2008; Grouiez 2011; Lukic 2013; Di Iacovo, O’Connor 2009; Wilson 2008; Kizos 2010; Dessein et al. 2013). Government policies, and especially EU policies, can play a crucial role in improving agri-food chain relationships; policies generally can in a straight line or not affect agri-food chains and can have macroeconomic or microeconomic objectives (Albisu et al. 2010). It is meaning highlighting that the EU aid programs do not replace the national policies, but only complements them; a horizontal, territorial-based policy of stimulating rural entrepreneurship should be investigated in order to balance it with a sectoral approach in a right political way (Bryla 2012). Improving rural areas is also linked to the promotion of sustainable growth and to creation of new employment opportunities, mainly for young people and women, as well as facilitating the access to advanced information and communication technologies.

The general approach for rural development in Apulia Region (Italy) is to secure a prominent position for the rural-areas, of the Apulia as well as European territory. This vision is pursued through sustainable rural development, by point of view economic as well as environmental that enables the rural population to achieve a higher living standard and a stable income level. According to Council Regulation (EC) N. 1698/2005, the support under axis 3 should involve: (a) measures to diversify the rural economy, comprising (1) diversification into non-agricultural activities for members of the farm household, (2) support for the creation and development of micro-enterprises of less than 10 employees, (3) encouragement of tourism activities; (b) measures to improve the quality of life in rural areas, comprising (1) basis services for the econo- my and rural population, (2) village renewal and development, (3) conservation and upgrading of the rural heritage; (c) a training and information measure; (d) a skills acquisition and animation measure. The support under axis 4 should involve: (e) implementing local development strategies through Local Action Groups (LAGs), with a view to achieving the objectives of one or more of the three other axes; (f) implementing cooperation projects involving the objectives selected; (g) running the local action group, acquiring skills and animating the territory. Piedmont's RDP programmed measures for each requirement, as shown in Table 1 .

Thus, rural tourism is not only the accommodation on farms, as stated by Trukhachev (2015: 3053), "Sustainability for rural areas is more than just a sustainable economic growth. The concept of sustainability in rural areas should integrate environmental, economical, cultural and social factors. Every component is of importance. However, the last factor is the critical one. The specific character of the agricultural production stipulates the main bottleneck: possibilities to replace labor and land with capital in rural areas are limited. At the same time, one of the most valuable competitive advantages of rural areas over urban ones is that they harmoniously combine natural and cultural values into a unique mixture of attractions. Rural tourism represent a alternative potential to provide income opportunities, which give firm agricultural a sustainable income that is competitive in comparison to that of urban territories. In this sense, the regional plan identified some measures particularly devoted to increase tourism in rual areas and the income of regional farms with the aim of making them more capable of dealing with an increasing worldwide competition".

\section{Data and methods}

The aim of this research paper is exploratory (Easterby-Smith et al. 1991), with this in mind; we have gathered data from the Management Authority of the Rural Development Plan of the Puglia Region, which has provided us with a database containing information at firms' level. More specifically, the database contains information on those firms which have equested to be admitted to the benefits of Measure 311 (Diversification into non-agricultural activities), Axes III, of the Rural Development Plan 2007-2013 through the first public call from 2011. We take in account as a case study the Puglia-Region - in Southern Italy where 25 Local Action Groups (LAGs) cover the 
Table 1. Programmed Axis 3 and 4 measures in Apulia Region RDP 2007-2013 (Source: ENRD 2010a, 2010b)

\begin{tabular}{|c|c|c|}
\hline \multicolumn{2}{|r|}{ Provided measures } & Measures programmed in Apulia Region \\
\hline \multirow[b]{3}{*}{$\begin{array}{l}\text { Measures to } \\
\text { diversify the } \\
\text { rural economy }\end{array}$} & $\begin{array}{l}\text { Diversification into non-agricultural activi- } \\
\text { ties for members of the farm household }\end{array}$ & 311 - Diversification into non-agricultural activities \\
\hline & Support for the creation and development & $\begin{array}{l}312 \text { - Support for business creation and develop- } \\
\text { ment }\end{array}$ \\
\hline & Encouragement of tourism Activities & $\begin{aligned} 313.1 \text { - } & \text { Encouragement of tourism activities con- } \\
& \text { nected to sustainable use of rural territory } \\
313.2 \text { - } & \text { Development of tourist services to support } \\
& \text { local offer (LAGs) }\end{aligned}$ \\
\hline \multirow{4}{*}{$\begin{array}{l}\text { Measures to } \\
\text { improve the } \\
\text { quality of life } \\
\text { in rural areas }\end{array}$} & $\begin{array}{l}\text { Basic services for the economy and rural } \\
\text { population }\end{array}$ & $\begin{array}{l}321.1 \text { - Accompanying to enterprise creation and } \\
\text { development (LAGs) } \\
\text { 321.2 - Innovative services for population (LAGs) } \\
321.3 \text { - Creation of polyfunctional centers (LAGs) } \\
321.4 \text { - Strengthening of broadband coverage }\end{array}$ \\
\hline & Village renewal and development & $322-$ Village renewal and development \\
\hline & $\begin{array}{l}\text { Conservation and upgrading of the rural } \\
\text { heritage }\end{array}$ & $\begin{array}{l}\text { 323.1 - Environmental protection and awakening } \\
323.2 \text { - Valorisation of the natural heritage (LAGs) } \\
323.3 \text { - Valorisation of the cultural heritage (LAGs) }\end{array}$ \\
\hline & Training and information & Training and information (LAGs) \\
\hline \multicolumn{2}{|c|}{$\begin{array}{l}\text { Implementing local development strategies, achieving the } \\
\text { objectives of one or more of the three other axes }\end{array}$} & $\begin{array}{l}411 \text { - Local development strategies (axis 1) (LAGs) } \\
412 \text { - Local development strategies (axis 2) (LAGs) } \\
413 \text { - Local development strategies (axis 3) (LAGs) }\end{array}$ \\
\hline \multicolumn{2}{|c|}{ Skills acquisition and animation measure } & 341 - Skills acquisition and animation \\
\hline \multicolumn{2}{|c|}{ Implementing cooperation projects } & 421 - Cooperation between LAGs (LAGs) \\
\hline \multicolumn{2}{|c|}{$\begin{array}{l}\text { Running the local action group, acquiring skills and } \\
\text { animating the territory }\end{array}$} & $\begin{array}{l}431 \text { - Running the local action group, acquiring } \\
\text { skills and animating the territory (LAGs) }\end{array}$ \\
\hline
\end{tabular}

entire region, data collection is related to 411 farms representing the total number of firms which have applied for aid of Measure 311 the entire Region and belonging to the 6 Puglia provinces: Bari (BA), Barletta-Andria-Trani (BAT), Foggia (FG), Lecce (LE), Brindisi (BR), Taranto (TA). Figure 2 shows the Puglia region.

The data analysis has been performed by following an integrated statistical approach consisting in two steps.

Firstly, in order to evidence the actual relation between own variables we use a discriminant analysis. Discriminant function estimators have often been used in logistic regression. Therefore, in this process is sought discriminant functions based on the independent variable to classify individuals according to the values of the dependent variable.

Henceforth, we have used the discriminant analysis because it helps identify the characteristics that differentiate (discriminate) two or more groups and to create a function able to distinguish as accurately as possible to members of both groups.

It has been a common practice to use discriminant function estimators as starting values in iterative maximum likelihood estimation and in exploratory data analysis, for the purpose of fitting logistic regression models.
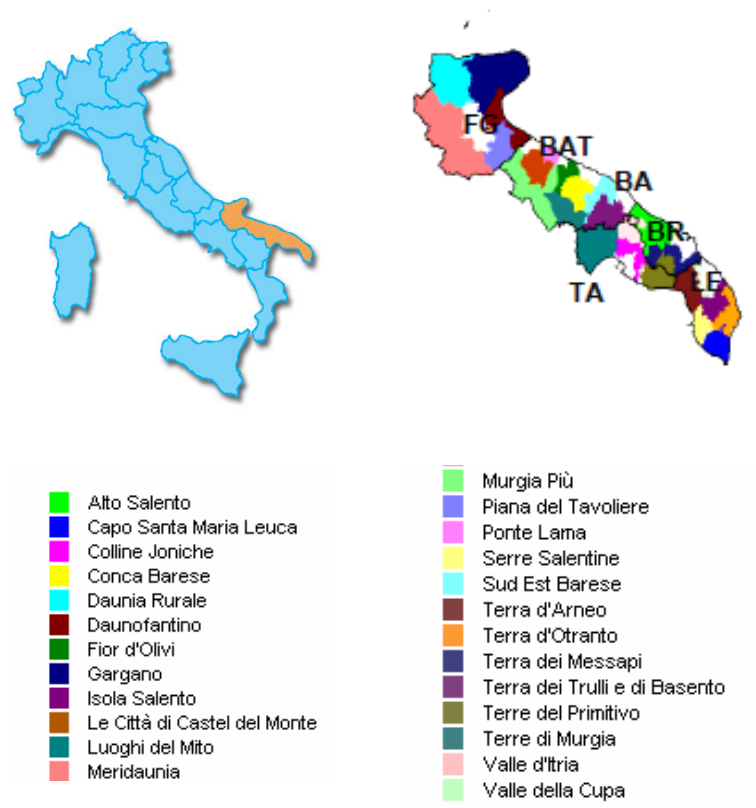

Fig. 2. LAGs covering the Puglia Region (Source: our processing on data by Puglia Region and the National Rural Network (Rete Rurale Nazionale... 2016)) 
The function is determinate by:

$$
\begin{aligned}
F(x)= & \frac{1}{\left[1+e^{-(a+b x))}\right]}, b \neq 0, \\
& -\infty<x<\infty .
\end{aligned}
$$

where $x=($ mean $) x$ it is the simple mean in a Taylor series. The unknown parameter $\alpha$ is a scalar constant term and $\beta$ is a $k \times 1$ vector with elements corresponding to the explanatory variables.

In our analysis we will consider the lambdaWilks statistic. This statistic expresses the proportion of total variability not due to differences between groups. Therefore it helps verify the null hypothesis that the mean Multivariate of groups (centroid) is equal (Wilks 1932).

The statistic is:

$$
\lambda=\frac{\text { Square sum intra }- \text { groups }}{\text { Total square sum }}=\frac{|S|}{|T|},
$$

where: $S$ is the matrix variance-covariance combined, calculated from the variance-covariance matrices for each group, and $T$ is the matrix of variance-covariance total calculated on all cases as if they belonged to a single group.

Bartlett (1947) showed that the statistical:

$$
v=\left|N-1-\frac{(p+g)}{2}\right| \ln \lambda,
$$

where it approximates the chi-square distribution with $(p-k)(g-k-1)$ degrees of freedom; $p$ is the number of independent variables or discriminants, $g$ is the number of groups, and $k$ is the number of discriminant functions obtained prior to contrast.

Secondly, the following method used in this paper is based on decision trees also called segmentation models. The main objective is to define and validate the models in order to determine which variables explain the variability of a dependent variable (Breiman et al. 1984).

This model is designed as an algorithm to build trees that are applied to regression and classification problems. They are explanative techniques that belong to the set of regression models but they have the advantage that both the criterion and the predictor variable may be either of quantitative or qualitative nature.

In this paper we will classify the cases into groups or predicts values of a dependent variable (target) based on values of independent variables (predictors). Therefore, the procedure provides us validation tools for exploratory and confirmatory analysis of classification that can be used in multiple techniques.

This kind of analysis identifies homogeneous groups with high or low risk and facilitates the construction of rules for making predictions about individual cases.

A first look at the data achieved by the Managing Authority above-mentioned enables us to observe how 411 firms have actually been admitted to the benefits of the measure in question. For each firm the database reports the following further information recorded at the time of the application: a. amount of the proposed investment; b. public aid granted; c. number of family and extra-family workers; d. revenues; e. production costs; f. farm size; g. investment implementation; i. regions.

The individuated variables are as follows: Investment, Farm size and Region, when the first two variables are quantitative, while the third variable is not quantitative, we can see on Table 2.

Table 2. Statistical variables subject of observation (Source: own elaboration)

\begin{tabular}{l|l|l}
\hline \multicolumn{2}{l}{} & $\begin{array}{l}\text { The total amount of the investment } \\
\text { proposed by the firm which derives } \\
\text { from the sum between public aid and } \\
\text { private capital }\end{array}$ \\
\hline 2 & Farm size & The size of the firm in ha \\
\hline 3 & Regions & $\begin{array}{l}\text { Is a geographic area where the firm } \\
\text { has the activity }\end{array}$ \\
\hline
\end{tabular}

\section{Results}

A first look at the data achieved by the Managing Authority above mentioned enables us to observe how 411 firms have actually been admitted to the benefits of the measure in question. For each firm the database reports the following further information recorded at the time of the application: a. amount of the proposed investment; $b$. public aid granted; c. number of family and extra-family workers; d. revenues; e. production costs; f. farm size, g. investment implementation; i. municipalities.

We describe the main results, and provide a first attempt at their interpretation. Likewise, we report the estimation results obtained from the selected models, and we obtain the main results.

Table 3 provides a numerical summary of valid cases in each discriminant variable. The information in this table has a special interest, because an unequal number of cases in each of the groups 
may affect the classification. In this case, Lecce represents $34.6 \%$ of the total investment analyzed.

Table 3. Equality of means test group (Source: own elaboration)

\begin{tabular}{l|c|c}
\hline \multicolumn{3}{c}{ Statistics per group } \\
\hline \multirow{2}{*}{ Province of belonging } & \multicolumn{2}{|c}{ N valid (for list) } \\
\cline { 2 - 3 } & unweighted & weighed \\
\hline Bari & 84 & 84.000 \\
\hline Brindisi & 43 & 43.000 \\
\hline Barletta- Andria- Trani & 15 & 15.000 \\
\hline Foggia & 73 & 73.000 \\
\hline Lecce & 115 & 115.000 \\
\hline Taranto & 2 & 2.000 \\
\hline Total & 332 & 332.000 \\
\hline Note: *Total Investment to new agritourism.
\end{tabular}

Table 4 shows the coefficient of Wilks' lambda value $(0.931)$, this outcome is not too small. Therefore, it is not too close to 0 so it is possible that the groups are not clearly separated. While the p-values and Chi-Squared certifies their exact statistical significance of the discriminant axis, which allows us to affirm that it has good explanatory power. So we can reject the null hypothesis that the groups being compared have equal averages the two discriminant variables.

Table 4. Equality of means test group (Source: own elaboration)

\begin{tabular}{c|c|c|c|c|c}
\hline & Wilk's Lambda & Chi-Squared & df1 & df2 & Sig. \\
\hline TI* $^{*}$ & .931 & 23.326 & 5 & 326 & .000 \\
\hline
\end{tabular}

Note: *Total Investment to new agrotourism.

The following table (e.g. see Table 5) gives an idea of how the functions distinguish/discriminate the groups. If the average of the groups in each function is very similar, thus the function does not discriminate groups. It is observed that discrimination is good for the function as assured earlier.

Table 5. Coefficients of canonical discriminant function (Source: own elaboration)

\begin{tabular}{l|c}
\hline & Function \\
\hline Total Investment to new agro tourism & 0.000 \\
\hline (Constant) & -1.658 \\
\hline Coefficients no standardized &
\end{tabular}

Table 6. Functions centroids of group (Source: own elaboration)

\begin{tabular}{c|c}
\hline Province of belonging & Function \\
\hline BA & -0.061 \\
\hline BR & 0.460 \\
\hline BT & 0.468 \\
\hline FG & -0.238 \\
\hline LE & -0.069 \\
\hline TA & 1.824 \\
\hline
\end{tabular}

Therefore, scores on the centroid of the groups (e.g. see Table 6) determine its position in the discriminant space. The central position is determined by replacing the variables in a discriminant equation by the mean values of the group variable.

As can be seen in the Figure 3, the classification model is determined by the decision tree.

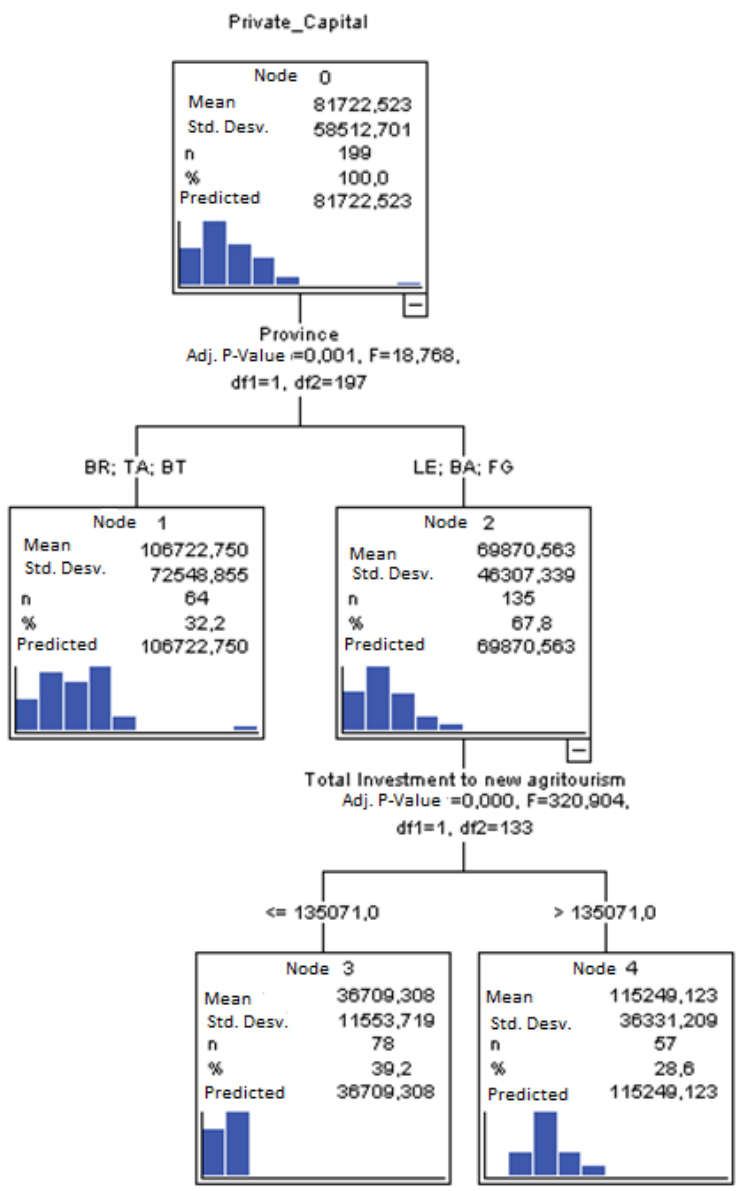

Fig. 3. Decision tree (Source: own elaboration)

It can be seen that the provinces that have greater influence on private capital are those corresponding to the Lecce, Bari, and Foggia corresponding to node 2 . The following predictor or independent variable is total investment to new 
agro-tourism. For those provinces with an investment level greater than or equal to 135.071 Euros (node 3) have a higher percentage with respect to relationship with the province and the private capital with a $39.2 \%$.

\section{Conclusions}

This paper has empirically analysed the relationship between the successful positive influences for farms and the diversifying its activities with respect to the tourism. We have analysed such case study the Puglia-Region - in Southern Italy.

In our empirical example, we found that the main issue in the relationship between difference of investment and tourism typology is not so much their bounded nature (near coastal) as we can think.

Nevertheless, we can say that the investment through Structural funds is a tool to increase the tourism in rural-areas and represent an alternative for the traditional structure (Hotel).

In order to draw a policy implication, it can be highlighted that a LAG can be a crucial driver to implement effective rural development strategies (Ramos, Garrido 2014) depending on the localization and on the initial context; thank to the special typical old rural structures in the farms, the Apulia LAGs can represent, in the long period, an effective planning tool for the local development.

In any particular, under no circumstances the position near the beach or sea is not very relevant regarding to Private Capital, inasmuch as the main regions that receive private capital are not all nearcoastal areas, for instance, the province of Foggia.

The future data collection will be carried out by means of investigating the annual income after the FMPs investments (not known in this period as the implementation is actually ongoing).

\section{Acknowledgements}

The authors would like to thank the Managing Authority of Puglia Region for the data provided. We are also grateful to jorunal's anonymous reviewers for their constructive comments, criticism and recommendations.

\section{References}

Aggelopoulos, S.; Samathrakis, V.; Pavloudi, A.; Hatzigeorgiou, C. 2006. Factor investigation leading to the development of women agrotourism enterpreneurship in Greece, in $24^{\text {th }}$ Eurochrie Conference, "Excellence for Tomorrow's Tourism, Travel and Hospitality”, 25-28 October 2006, Thessaloniki, Greece.
Albisu, L. M.; Henchion, M.; Leat, P.; Blandford, D. 2010. Improving agri-food chain relationships in Europe: the role of public policy, in C. Fischer, M. Hartmann. (Eds.). Agri-food chain relationships. CABI, 250-266.

http://dx.doi.org/10.1079/9781845936426.0045

Andrei, J.; Darvasi, D. 2012. Perspectives and challenges in financing the new common agricultural policy, a new paradigm, Journal of Food, Agriculture and Environment 10(1): 904-907.

Bartlett, M. S. 1947. Multivariate analysis, Journal of the Royal Statistical Society B 9: 176-197. http://dx.doi.org/10.2307/2984113

Breiman, L.; Friedman, J. H.; Olshen, R. A.; Stone, C. J. 1984. Classification and regression trees, Biometrics 40(3): 874. Belmont: Wadsworth.

Bryla, P. 2012. The characteristics of farmers applying for the EU investment support in Poland, Agricultural Economics 58(1): 21-33.

http://dx.doi.org/10.2307/2530946

Chen, C. 2011. Researches on application of the renewable energy technologies in the development of low-carbon rural tourism, Energy Procedia 5: 1722-1726.

http://dx.doi.org/10.1016/j.egypro.2011.03.293

Ciani, A. 2012. The Rural Tourism and Agritourism: a new opportunity for agriculture and rural areas (Between Pluria-activity, Multifunctionality, Sustainable Development Strategy and Green Economy Growth), in Atas do VIII-CITURDESCongreso Internacional de Turismo y Desenvolvimiento Sustentavel "Turismo rural em tempos de novas ruralidades", 25-27 June 2012, UTAD, Chaves, Portugal.

Council Regulation (EC) No 1698/2005 of 20 September 2005 on support for rural development by the European Agricultural Fund for Rural Development (EAFRD).

Dessein, J.; Bock, B. B.; de Krom, M. P. 2013. Investigating the limits of multifunctional agriculture as the dominant frame for green care in agriculture in Flanders and the Netherlands, Journal of Rural Studies 32: 50-59. http://dx.doi.org/10.1016/j.jrurstud.2013.04.011

Di Iacovo, F.; O'Connor, D. 2009. Supporting policies for social farming in Europe. Progressing multifunctionality in responsive rural areas. SoFar project: supporting EU agricultural policies. D. O'Connor (Ed.). Firenze, ARSIA.

Easterby-Smith, M.; Thorpe, P.; Lowe, A. 1991. Management research: an introduction. Newbury Park, CA: Sage Publications.

European Network for Rural Development (ENRD). 2010a. Overview of Social Farming and Rural Development Policy in Selected EU Member States [online]. Bruxelles, European Commission [cited January 2016]. Available from Internet: http://enrd.ec.europa.eu/enrd-static/fms/pdf/ A9746FA3-0D7E-1772-5CC7-11217C8EC059.pdf 
European Network for Rural Development (ENRD). 2010b. Rural Development Programme for Puglia 2007-2013 [online], [cited January 2016]. Available from Internet: http://enrd.ec.europa.eu/enrdstatic/fms/pdf/EB007ED3-CC2C-B128-12E5C75B484E4926.pdf

European Commission. 2013a. Overview of the EU rural development policy 2007-2013 [online], [cited 20 January 2015]. Available from Interent: http://ec.europa.eu/agriculture/statistics/agricultura 1/2013/index_en.htm

European Commission. 2013b. Rural development in the European Union - statistical and economic information report 2013 [online], [cited January 2016]. Available from Internet:

http://ec.europa.eu/agriculture/statistics/ruraldevelopment/2013/full-text_en.pdf

Eurostat. 2013. Agriculture, forestry and fishery statistics 2013 edition [online]. ISSN 1977-2262 [cited Juanary 2016]. Available from Internet: http://ec.europa.eu/eurostat/documents/3930297/59 68754/KS-FK-13-001-EN.PDF

Farm Accountancy Data Network. 2010. Developments in the income situation of the EU agricultural sector [online], [cited Juanary 2016]. Available from Internet: http://ec.europa.eu/agriculture/rica/pdf/ hc0301_income.pdf

Grouiez, P. 2011. Les stratégies des exploitations agricoles et la multifonctionnalité de l'agriculture russe [Farm strategies and the multifunctionality of Russian agriculture], Revue d'Etudes Comparatives Est-Ouest, Nr. 42 (in French). http://dx.doi.org/10.4074/S0338059911002075

Hjalager, A. 1996. Agricultural diversification into tourism: Evidence of European community development programme, Tourism Management 17(2): 103-111. http://dx.doi.org/10.1016/0261-5177(95) 00113-1

Johnston, B. F.; Mellor, J. W. 1961. The role of agriculture in economic development, American Economic Review 51(4): 566-593.

Jongeneel, R. A.; Polman, N. B. P.; Slangen, L. H. G. 2008. Why are Dutch farmers going multifunctional, Land use Policy 25(1): 81-94. http://dx.doi.org/10.1016/j.landusepol.2007.03.001

Kasimis, C. 2010. Demographic trends in rural Europe and international migration to rural areas, Rural Sociology 59(3): 571-579. http://dx.doi.org/10. 1111/ j.1549-0831.1994.tb00548.x

Kizos, T. 2010. Multifunctionality of farm households in Greece, Norsk Geografisk Tidsskrift 64(2): 105116. http://dx.doi.org/10.1080/00291951.2010.481137

Kuznets, S. 1964. Economic growth and the contribution of agriculture: notes for measurement, in C. Eicher, L. Witt (Eds.). Agriculture in economic development. New York: McGraw-Hill.
Liu, J.; Feng, T.; Yang, X. 2011. The energy requirements and carbon dioxide emissions of tourism industry of Western China: a case of Chengdu city, Renewable and Sustainable Energy Reviews 15: 2887-2894. http://dx.doi.org/10.1016/j.rser.2011.02.029

Lukic, A. 2013. Tourism, farm diversification and plurality of rurality: case study of Croatia, European Countryside 5(4): 356-376. http://dx.doi.org/10.2478/euco-2013-0023

Mellor, J. W. 2000. Faster more equitable growth: the relation between growth in agriculture and poverty reduction. Consulting Assistance on Economic Reform II. Discussion Paper No. 70. Abt Associates Inc. Massachusetts: Harvard Institute for International Development.

OECD. 2003. Multifunctionality: the policy implications [online]. Paris: OECD Publications [cited October 2015]. Available from Internet: http://www.oecd. org/tad/agricultural-policies/40782915.pdf

OECD. 2005. Multifunctionality in agriculture: what role for private initiatives [online]. Paris: OECD Publications [cited Juanary 2016]. Available from Internet: http://www.oecd.org/agriculture/agricultu ral-policies/40782982.pdf

OECD. 2006. The new rural paradigm: policies and gobernance [online]. Paris: OECD Publications [cited Juanary 2016]. Available from Internet: http://www3.unisi.it/cipas/ref/OECD_2006_Rural_ Paradigm.pdf

OECD. 2008. Multifunctionality in agriculture: evaluating the degree of jointness, policy implications [online] Workshop Report. Paris: OECD Publications [cited November 2015]. Available from Internet: http://www.keepeek.com/Digital-AssetManagement/oecd/agriculture-and-food/ multifunctionality-in-agriculture_9789264033627en\#page 1

Ohe, Y. 2007. Multifunctionality and rural tourism: a perspective on farm diversification, Journal of International Farm Management 4(1): 1-23.

Popescu, G.; Andrei, J. 2011. From industrial holdings to subsistence farms in the Romanian agriculture. Analyzing the subsistence components of the CAP, Agricultural Economics 57(11): 555-564.

Psaltopoulos, D.; Efstratoglou, E. 2000. An empirical evaluation of EU and national structural policies in remote rural areas: the case of Everytania, Agricultural Economic Review 1: 7-18.

Ramos, E.; Garrido, D. 2014. Territorial rural development strategies based on rural specificites: the case of the rural quality mark in Spain, Revista De Estudios Regionales 100: 101-129.

Rete Rurale Nazionale 2014-2020 [online]. 2016 [cited Jaunary 2016]. Available from Internet: http://www.reterurale.it (in Italian). 
Rural Development Programme 2007-2013 Apulia Region approved by Decision C20139700 of $19 / 12 / 2012$. Management Authority of the Rural Development Plan (in Italian).

Sanagustin Fons, M. V.; Monsene Fierro, J. A.; Gomez Patino, M. 2011. Rural tourism: a sustainable alternative, Applied Energy 88: 551-557. http://dx.doi.org/10.1016/j.apenergy.2010.08.031

Schaerer, J.; Dirven, M. 2001. El turismo rural en Chile: experiencias de agroturismo en Las Regiones del Maule [Rural tourism in Chile: experiences of agrotourism in the Maule region]. La Araucania y Los Lagos. CEPAL (in Spanish).

Sharpley, R.; Vass, A. 2006. Tourism, farming and diversification: an attitudinal study, Tourism Management 27(5): 1040-1052. http://dx.doi.org/10.1016/j.tourman.2005.10.025

Stoate, C. 2008. Multifunctionality in practice: research and application within a farm business, in Book Sustainable farmland management: transdisciplinary approaches. CABI, 161-168. http://dx.doi.org/10.1079/9781845933517.0161

Trukhachev, A. 2015. Methodology for evaluating the rural tourism potentials: a tool to ensure sustainable development of rural settlements, Sustainability 7: 3052-3070.

http://dx.doi.org/10.3390/su7033052
Van der Ploeg, J. D.; Renting, H.; Brunori, G.; Knickel, K.; Mannion, J.; Marsden, T.; De Roest, K.; Sevilla-Guzmán, E.; Ventura, F. 2000. Rural development: from practices and policies towards theory, Sociologia Ruralis 40(4): 391-408. http://dx.doi.org/10.1111/1467-9523.00156

Van der Ploeg, J. D.; Laurent, C.; Blondeau, F.; Bonnafous, P. 2009. Farm diversity, classification schemes and multifunctionality, Journal of Environmental Management 90(Supplement 2): S124S131. http://dx.doi.org/10.1016/j.jenvman.2008.11.022

Wilks, S. S. 1932. Certain generalizations in the analysis of variance, Biometrika 24(3): 471-494. http://dx.doi.org/10.1093/biomet/24.3-4.471

Wilson, G. A. 2008. From "weak" to "strong" multifunctionality: conceptualising farm-level multifunctional transitional pathways, Journal of Rural Studies 24(3): 367-383.

http://dx.doi.org/10.1016/j.jrurstud.2007.12.010 